described, it might be said that this takes place along an asymptotic curve, continually approaching but never becoming equal to zero.

According to the other, protoplasm passes absolutely from the kinetic to the static condition. Its locked-up energy becomes purely potential, and Professor C. de Candolle has not hesitated under these circumstances to compare it to an explosive.

It has been pointed out that such a conclusion is absolutely in conflict with Mr. Herbert Spencer's well-known definition of life. But it appears to me that that definition was only intended to apply to higher stages of the aggregation of living matter than that of the physiological molecule on which I have endeavoured to fix the discussion. The question seems to me to be simply whether it is admissible to regard that as capable of being brought to an absolutely static condition.

Conceive two such molecules, one known to be living, but static, and the other dead, and both to be maintained in a condition in which they are not immediately susceptible to chemical change. What is the criterion of life? There is none. It seems to me then that the question I have propounded does not admit of any positive answer in the present state of our knowledge.

A problem, perhaps somewhat scholastic, which once vexed the souls of biologists was-whether life was the cause of organization or organization of life. What is to be our answer if our startingpoint is no more than a possible 'explosive'?

\title{
ON THE STRUCTURE OF THE STEM OF A RIBBED
} SIGILLARIA ${ }^{1}$. By Professor C. E. Bertrand.-The structure of certain species of Lepidodendron, e.g. L. selaginoides and L. Harcourtii, is well known, and we are in possession of some facts as to the anatomy of Sigillaria spinulosa and S. Menardi, species which belong to the section of the genus characterized by a smooth bark (Leiodermaria). On the other hand, we are still in want of data with regard to the structure of the Rhytidolepis section of Sigillariathe species with a ribbed bark. It has been suggested that some of the stems described under the name Diploxylon may very probably be partially decorticated Sigillarias.

In March of this year (1899) I received from the colliery of

1 Abstract (translated) of a paper read before the Botanical Section of the British Association, Dover, Sept. I 899 . 
Glaneuse, in the Haidinghen district, Pas de Calais, a piece of a ribbed Sigillarian stem, which presented a recognizable external surface, while, at the same time, the wood of the central cylinder was clearly preserved. The specimen may probably be referred to Sigillaria elongata; the possible error does not exceed the difference which separates $S$. elongata from $S$. scutellata. It was found by M. Ludovic Breton and his son, M. Eug. Breton, in a seam of coal known as the 'Veine perdue.' The fragment measures $100 \mathrm{~mm}$. in diameter and $60 \mathrm{~mm}$. in height, and the surface is traversed by seventy-two ribs, of which forty-eight are visible and twenty-four are hidden by a fold of the surface. The structure of the wood, which is in places perfectly preserved, agrees on the whole with that of a Diploxylon, and the primary xylem constitutes a continuous, centripetally developed corona. Externally, this is enclosed by a continuous zone of centrifugal secondary wood, but the cambial and phloem regions, and also the central tissues, have completely disappeared. The carbonized peripheral region of the stem consists of sclerous tissue, of which the elements have thin brown walls and contain an amorphous yellow substance.

The continuous corona is made up of ten to thirteen rows of large scalariform tracheides, without any free lignified elements internal to the primary xylem, which consists solely of tracheides without any interposed primitive fibres ('fibres primitives'); in the latter respect the French specimen differs from one of the Diploxylon stems from the coal-measures of Oldham. The external face of the corona is characterized by very prominent teeth corresponding to the furrows of the external surface. The prominent teeth alternate regularly with the sinuses. The smallest xylem-elements are situated in the projecting teeth. In a region of the corona, at some distance from the point of exit of a leaf-trace, the spiral tracheae are arranged in two superficial groups laterally placed in relation to the projecting teeth; but in the immediate neighbourhood of the origin of a leaf-trace, the spiral elements form a median band in the middle of a sinus. The large tracheides of the primary wood represent its cauline portion ('partie réparatrice'). The leaf-traces arise from the external face of the corona, and each is detached from the middle of a sinus. The leaftraces of every alternate sinus are cut almost at the same level, an arrangement which points to an almost regularly verticillate disposition of the leaves. 
Each leaf-trace springs from the small external elements of the xylem, and consists of six tracheae in the form of a tangentially extended group, and of six to eight radially disposed centripetal bands of scalariform tracheides, each band including four elements. The foliar bundles consist of primary xylem only, and follow a radial course through the medullary rays of the secondary wood.

The secondary wood is twenty-three elements in thickness; the arc opposite each sinus of the corona is composed of ten to twelve radial bands of tracheides, while the arc opposite a projecting tooth of the course includes four to six bands. There are thus thirty-two radial series of tracheides between two outgoing leaf-traces; the elements opposite the teeth are somewhat smaller in diameter than in the xylem opposite the sinuses, but the difference is very slight.

In Sigillaria spinulosa from Autun the leaf-traces arise from the same point in the corona as in the ribbed stem from Haidinghen; their arrangement and the structure of the wood is also the same; but in the former species the primary wood occurs in the form of distinct groups or islands occupying positions corresponding to the sinuses in the corona of the ribbed Sigillaria. In S. spinulosa there is no primary xylem in the positions corresponding to the teeth on the surface of the corona of the Haidinghen stem. The polar regions ('régions polaires'), which tend to be differentiated in the projecting teeth of the corona of the ribbed Sigillaria, are not represented in the corona of the Leiodermarian type of stem. Moreover, as Renault has stated, the leaf-traces of the latter type of Sigillaria consist in part of secondary xylem. The arrangement of the spiral elements is also different in the two species. In $S$. spinulosa there are ten to fourteen radial bands of secondary tracheides opposite each group of primary xylem, and four to six bands of smaller elements opposite each interval separating the detached groups of which the corona is composed. In the number (thirty-two to thirty-four) of radial series between two outgoing traces, the two species agree. We see, therefore, that there is a close agreement in the structure of the Leiodermaria and Rhytidolepis types as regards the manner of exit of the leaf-traces; but the disposition of the small protoxylem-elements affords a striking distinction. In the Autun Sigillaria there is also a tendency to differentiate the secondary wood opposite the sinuses from that opposite the teeth.

A comparison of the ribbed Sigillaria of Haidinghen, with the 
Diploxylon stems from Halifax and Oldham, and the Lepidodendroid stem from Burntisland, shows that the primary xylem becomes broader in this series of forms. The polar groups of small elements, which still form strongly prominent teeth on the surface of the corona in the stems from Halifax and Oldham, are considerably reduced in the Burntisland plant, just as in Lepidodendron selaginoides. The leaf-trace, which is still given off from the middle of a sinus in the Halifax and Oldham stems, arises laterally, in relation to the teeth of the corona, in the Burntisland stem, approaching Lepidodendron selaginoides in this point also. The secondary wood of the Burntisland form shows no indication of any differentiation of the secondary wood into segments or arcs corresponding to the sinuses and teeth of the primary wood. In fact, certain English types of Diploxylon only accentuate the differences which separate the Haidinghen Sigillaria from $S$. spinulosa.

The central axis of the ribbed Sigillaria differs from that of the Phanerogamic type in the manner of origin of the leaf-traces and in the structure and centripetal development of the primary xylem; these structural features characterize the radial form of vascular axis, and are in short those of a well-defined Cryptogamic type.

THE JURASSIC FLORA OF BRITAIN ${ }^{1}$. - The Jurassic plantbearing strata exposed in the cliff sections of the Yorkshire coast, between Whitby and a few miles south of Scarborough, have afforded unusually rich data towards a restoration of the characteristics and composition of a certain facies of Mesozoic vegetation. Since the publication of A Geological Survey of the Yorkshire Coast, by Young and Bird, in 1822 , the numerous species of Inferior Oolite plants from Gristhorpe Bay, Scarborough, Cloughton Wyke, Haiburn Wyke, Whitby and other localities have been described by Phillips, Brongniart, Lindley and Hutton, Morris, Göppert, Leckenby, Saporta, Zigno, Nathorst, Carruthers and other writers, but no detailed account of the flora has been published. The names of Bean, John Williamson, his son William Crawford Williamson, Phillips, Murray, Leckenby and others will always be closely associated with the earlier investigations of the fossil flora of east Yorkshire. The British Museum unfortunately possesses but few of the type-specimens of these Jurassic plants ;

${ }^{1}$ Read before the Botanical Section of the British Association, Dover, Sept. I 899. 


\section{$2 \mathrm{BHL}$ Biodiversity Heritage Library}

Bertrand, C.-Eg. 1899. "On the structure of the stem of a ribbed Sigillaria." Annals of botany 13, 607-610.

https://doi.org/10.1093/oxfordjournals.aob.a088753.

View This Item Online: https://www.biodiversitylibrary.org/item/232524

DOI: https://doi.org/10.1093/oxfordjournals.aob.a088753

Permalink: https://www.biodiversitylibrary.org/partpdf/318559

\section{Holding Institution}

Smithsonian Libraries

\section{Sponsored by}

Biodiversity Heritage Library

\section{Copyright \& Reuse}

Copyright Status: Not in copyright. The BHL knows of no copyright restrictions on this item.

This document was created from content at the Biodiversity Heritage Library, the world's largest open access digital library for biodiversity literature and archives. Visit BHL at https://www.biodiversitylibrary.org. 